\title{
Tripterygium Wilfordii Extract (Triptolide) and Amygdalin Promotes Cell death in Cancer Cells: True or a Myth
}

\author{
Patrikios Ioannis*, Stephanou Anastasis, Yiallouris Andreas \\ School of Medicine, European University Cyprus, Nicosia Cyprus \\ *Corresponding author: I.Patrikios@euc.ac.cy; patrikiosioannis@gmail.com
}

Received May 06, 2015; Revised July 14, 2015; Accepted September 07, 2015

\begin{abstract}
Different natural products are known for their use in conventional medicine and especially for their beneficial effect on chronic diseases including autoimmune and cancer. A purified natural extract sample from the Chinese herb Tripterygium wilfordii Hook F (known as Lei Gong Teng or Thunder of God Vine) containing diterpenoids and triepoxides, was associated with significant anti-tumor effects and with encouraging results. Additionally, another natural extract from apricot kernels, Amygdalin (also known as laetrile or vitamin B17) a cyanide- containing substance, has been reported as a potential anti-cancer molecule with numerous contradictions among different published data. For many years different scientist tried to investigate in vivo, in vitro and ex vivo the efficacy of all of these molecules but they all failed in giving clear robust positive conclusions and the opinions are contradictory. Most of the studies were focusing on the apoptotic effects that can lead to the programmed cell death (PCD), a noteworthy mechanism in cancer treatment. The present review summarizes published reports and gives a better understanding of the known abilities as well as the possible role of these specific natural extract molecules in the fight of cancer treatment, cure and prevention.
\end{abstract}

Keywords: cell death, apoptosis, Triptolide, Amygdalin, Vitamin B17, anti-cancer agents

Cite This Article: Patrikios Ioannis, Stephanou Anastasis, and Yiallouris Andreas, "Tripterygium Wilfordii Extract (Triptolide) and Amygdalin Promotes Cell death in Cancer Cells: True or a Myth." American Journal of Cancer Prevention, vol. 3, no. 4 (2015): 77-83. doi: 10.12691/ajcp-3-4-3.

\section{Introduction}

Traditional Chinese Medicine (TCM) using mostly natural products has been used throughout the centuries for the treatment and cure of inflammation, chronic diseases in general including cancer; and for the manufacture of pharmaceutical products aiming to treasure the cure for various diseases of millions of people worldwide. [1,2] "Thunder of God", one of the Chinese medicinal herbs that belongs to genus Tripterygium, grows usually in the mountainous regions of southeast and southern China. In the 1930's it was used as insecticide in the Western science and as potential medicinal plant in the 1960 's. The name comes from Charles Wilford, a botanical collector at London Kew Botanical Gardens (1857-1860). He found the plant on the island of Formosa (now Taiwan) in June 1858. [3] The literature review demonstrates encouraging therapeutic potentials of Tripterygium wilfordii Hook $\mathrm{F}$ (TwHf) and its natural extract, the Triptolide, in many autoimmune and inflammatory conditions (Figure 1A). [4,5] Different phase $2 \mathrm{~b}$ clinical trials have been performed investigating the efficacy of TwHf extracts on several diseases such as rheumatoid arthritis (RA), Crohn's disease and kidney transplantation. [6,7] Previous studies have demonstrated anti-inflammatory and anticancer activity. [8-15] Moreover, Triptolide proapoptotic and antiproliferative activity has also been associated with a numerous cancer cell lines in vitro and in vivo such as: HL-60, T cell lymphoma (Jurkat), U937, OCI-AML3 Kasumi-1 and SKNO-1 cells, human hepatocellular carcinoma SMMC7721 cells, and cell lines of multiple myeloma, breast, gastric, prostate, lung, oral, colon, pancreatic and cervical cancers, cholangiocarcinoma, and neuroblastoma. [8-15] In vivo trials confirmed the therapeutic activity of Triptolide in a number of model systems including hamster models, human melanoma xenografts, gastric carcinoma, breast cancer, pancreatic cancer, bladder cancer and neuroblastoma in nude mice studies. $[16,18]$ Moreover, Triptolide has been shown to fortify other agents helping as combination with other drugs to improve their cancer treatment abilities. [19,20,21] Some of the recorded side effects were diarrhea, headache, nausea and infertility. As a result, the safety issue was one of the major reasons that led to numerous attempts for the improvement of its biochemical properties including both safety and efficacy. [22,23] The therapeutic indications of TwHf extract can be associated with more than 100 molecules such as diterpenes, triterpenes, sesquiterpenoids, and alkaloids, found in the natural extract samples; and are used for the treatment of various diseases. [24,25,26] On the other hand, a number of these molecular components 
were shown to be associated with anti-fertility effects in male animal models. [27,28] Even though advances have been made towards the understanding of the molecular mechanisms of the aforementioned compounds, the precise targets of Triptolide and the major compounds found within the TwHf extract remain unclear. As a result, more precise pre-clinical studies have yet to be performed to ensure safety of the Triptolide molecule as well as a clear understanding of its way of biomechanical action.

\section{(A)}

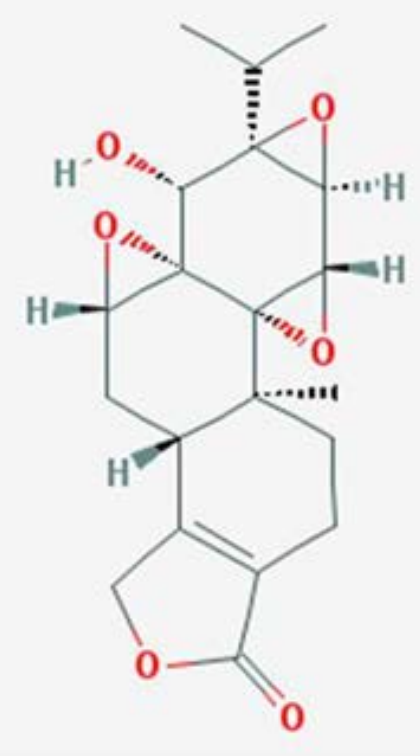

(B)

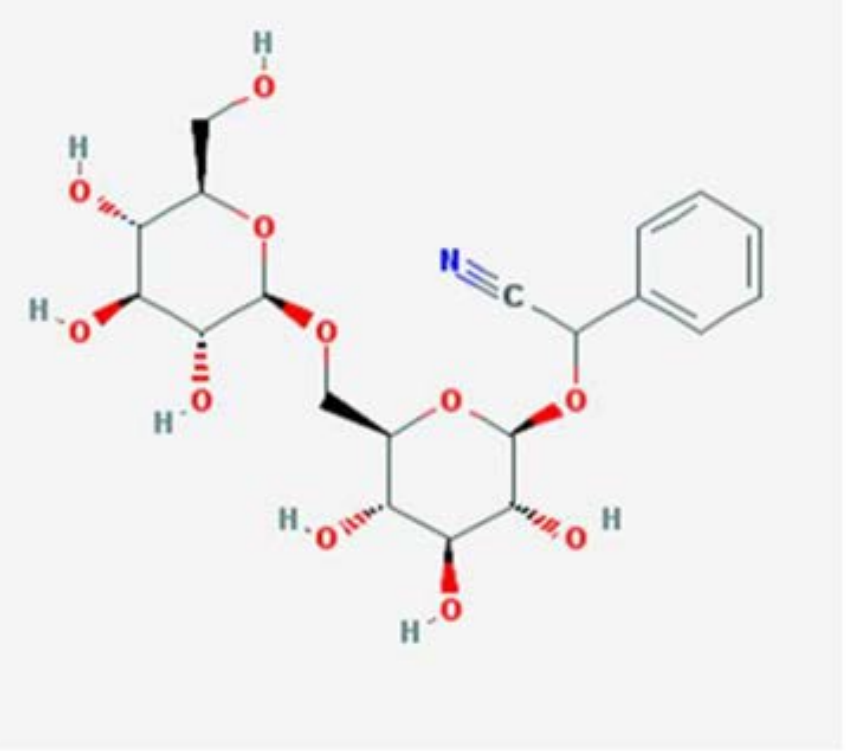

Figure 1. Molecular structures of (A) Tripterygium wilfordii Hook F (Triptolide) and (B) Amygdalin (provided by Pubchem)

Amygdalin (vitamin 17) belongs in the nitrilosides molecules family and previously called laetrile (Figure 1B). Furthermore Amygdalin has been reported as a natural anti-cancer extract containing cyanide and it is abundant in the seeds of Prunasin family like apricots, almonds, peaches, apples, and other rosaceous plants. Including in the Prunasins, Armeniacae semen has also been used for the treatment of colorectal cancer, leucoderma, bronchitis, emphysema, asthma, leprosy and pain. [29,30,31] The structure of Amygdalin contains two molecules of glucose, one of benzaldehyde that induces an analgesic action, and one of hydrocyanic acid, that is an anti-neoplastic compound. Over the above actions, Amygdalin has been shown to treat several types of cancer as well as a pain relief. [32,33,34] Moreover, Amygdalin has been demonstrated to selectively induce cancer cells death. [35] The impact of Amygdalin in the prevention and control of cancer has also been analyzed and reviewed. [36,37] It is important to emphasize that due to its cyanide functional group and the potential toxicity, there is a dechognomy among the scientific community for the use of Amygdalin as a cancer treatment. [36,37,38] However, Moertel et al. (1981) revealed that, in humans, intravenous infusion of Amygdalin did not cause cyanidemia nor signs of toxicity. In contrary, the oral administration of Amygdalin resulted in significant blood cyanide levels and in one case, oral Amygdalin in combination with almond extract produced transient symptoms of cyanide intoxication and further increase of blood cyanide as reported by Moertel et al. (1981). [38,39] Additionally, Fukuda et al. (2003) previously reported that Amygdalin and other components of Prunus Persica seeds have anti- cancer properties. While Kwon et al. (2003) demonstrated that Persicae semen was able to convert the active anti-cancer form from its inactive form [40].

Overall, despite the fact that there is a growing interest regarding the possible anti-cancer properties of Amygdalin, there are no reports proving how it mediates its anti-cancer activity. This short review is based on information collected through the literature review and we will attempt to further our understanding and to answer a crucial question: "Triptolide and Amygdalin promotes cell death in cancer cells: true or a myth"; that stands for decades under strong debate among the scientific community.

\section{Triptolide and Amygdalin 'Friend or Foe'}

\section{Triptolide and Amygdalin as potential anticancer agents \\ Triptolide}

Triptolide, as a molecule with anti-cancer activity potential, has attracted the interest of many scientists and researchers. [41] Studies on prostate cancer cells revealed some interesting information. For example, human prostatic epithelial cells derived from normal tissues and adenocarcinomas in primary cultures showed extreme resistance to apoptosis. [41] The function of wild-type p53 is diminished in particular cell lines, due to the fact that the drugs requiring p53 activity to induce cell death are rather ineffective. As a result, the potential properties of Triptolide helped towards its recent water-soluble form (PG490-88) approval for Phase I clinical trials for antitumor activity against prostate cancer (Table 1). [41] Experiments were previously performed to show that 
Triptolide had direct effect on both normal and several different cancer cell lines. At low concentration Triptolide inhibited cell proliferation and promoted a senescence-like phenotype. In contrast high concentration of Triptolide increased apoptosis that was not associated with the effects of p53 induced cell death. [41] However inconsistently p53 target genes such as p21WAF1/CIP1 and hdm-2, were reduced, as was bcl-2. [41] A number of preclinical studies suggested that Triptolide could be an effective, preventive as well as therapeutic agent against prostate cancer and that Triptolide might be mediating its effect via a p53 mediated pathway [41].

Table 1. Previously published work on Tripterygium Wilfordii extract

\begin{tabular}{|c|c|c|c|}
\hline \multicolumn{4}{|c|}{ TRIPTOLIDE } \\
\hline Trial Design & Results & Randomized & Reference \\
\hline Phase I clinical trial & Anticancer activities against prostate cancer & $* \mathrm{~N} / \mathrm{A}$ & Taija et al. (2002) [41] \\
\hline in vitro & Promotes apoptosis in laryngocarcinoma cells & N/A & Fei et al. (2013) [42] \\
\hline in vivo & Inhibitory effect on colon cancer & N/A & Zhipeng et al. (2009) [43] \\
\hline Clinical trials & Tripterygium wilfordii Toxicity & No & $\begin{array}{l}\text { Takei et al. (1997) [51] } \\
\text { Xu et al. (2004) [53] }\end{array}$ \\
\hline Clinical trials & Antifertility in Humans & No & $\begin{array}{l}\text { Lopez et al. (2005) [55] } \\
\text { Zhen et al. (1995) [57] }\end{array}$ \\
\hline Clinical trials & Renal toxicity & No & Ji et al. (2006) [60] \\
\hline in vitro and in vivo & Cytotoxicity & N/A & $\begin{array}{l}\text { Chang et al. (1997) [64] } \\
\text { Sylvester et al. (2001) [67] }\end{array}$ \\
\hline Clinical trials & $\begin{array}{l}\text { Triptolide is reported with beneficial effects on } \\
\text { RA with clinically important side effects. }\end{array}$ & Yes & $\begin{array}{l}\text { Little et al. (2001) [71] } \\
\text { Cameron et al. (2009) [72] }\end{array}$ \\
\hline
\end{tabular}

*N/A: Not Applicable.

Taking into consideration the fact that the toxicity of Triptolide on cancer cells included apoptosis induction activity, a further examination of the apoptosis induction effect of Triptolide in Hep-2 cells was examined. Triptolide subjected to analysis by flow cytometry induce cells to accumulate in sub-G1 phase in a dose dependent manner and induced Annexin V (AV)-FITC and PI double staining of both early (AV+/PI-) and late apoptotic cells $(\mathrm{AV}+\mathrm{PI}+)$. These results strongly indicated that Triptolide efficiently induced apoptosis in laryngocarcinoma cells. [42] Furthermore Triptolide was showed to promote apoptosis that involve both intrinsic and extrinsic pathways. Thus, both activated caspase-8/-9 cleaves the effector caspase- 3 to promote cell apoptosis. One of the targets of caspase-3, PARP was also cleaved. These results therefore confirmed that Triptolide efficiently induced apoptosis in laryngocarcinoma cells [42].

Additionally, Triptolide has been reported to reduce growth of primary tumors in nude mice. The in vivo testing of Triptolide on colon cancer highlights Triptolide's effects. [43] When Triptolide was administered to mice with established primary tumor xenografts, the results were significantly positive. The outcomes showed that Triptolide had a positive inhibitory effect on the growth of all tumor cell lines in a dose-dependent manner. Tumor xenografts demonstrated that Triptolide reduced the levels of IL6R, JAK1 and phosphorylation of STAT3. In contrast Rac1 levels were unchanged. Moreover, the growth of DN17-Rac1 transformed cells were significantly lower than non-transformed tumor cells in nude mice and the CA-Rac1 transformed cells grew faster than non-transformed tumor cells [43].

\section{Amygdalin (laetrile or vitamin B17).}

Amygdalin is another molecule under strong debate, for its effectiveness in the viability of prostate cancer cell. In particular, DU145 and LNCaP cells treated with Amygdalin exhibited several morphological characteristics of apoptosis. Amygdalin treatment increased the expression of Bax, a pro-apoptotic protein, and decreased the appearance of Bcl-2, an anti- apoptotic protein, while increasing caspase-3 enzyme activity in DU145 and LNCaP prostate cancer cells. [44] Thus, it could be concluded that Amygdalin can possibly induce apoptotic cell death in human DU145 and LNCaP prostate cancer cells by activating the caspase- 3 and down-regulation of Bcl-2 and up regulation of Bax. [44] The current literature review reveals that Amygdalin may offer valuable aid for the treatment of prostate cancers by promoting apoptotic cell death [44].

Table 2. Previously published work on Amygdalin

\begin{tabular}{|c|c|c|c|}
\hline \multicolumn{4}{|c|}{ AMYGDALIN } \\
\hline Trial Design & Results & Randomized & Reference \\
\hline in vitro & $\begin{array}{l}\text { Morphological characteristics of apoptosis, expression of Bax } \\
\text { (proapoptotic protein) }\end{array}$ & $* \mathrm{~N} / \mathrm{A}$ & Hyun-Kyung et al. (2006) [44] \\
\hline in vitro & $\begin{array}{l}\text { Antimicrobial and antioxidant activities against human } \\
\text { pathogenic microorganisms }\end{array}$ & N/A & Moertel et al. (1982) [46] \\
\hline in vitro & $\begin{array}{l}\text { Amygdalin down-regulates genes belonging to cell cycle in } \\
\text { colon cancer cells }\end{array}$ & N/A & Hae-Jeong et al. (2005) [49] \\
\hline in vivo & Hazardous in Humans and animals & N/A & $\begin{array}{l}\text { Humbert et al. (1977) [83] } \\
\text { Schmidt et al. (1978) [80] }\end{array}$ \\
\hline in vivo & Animal poisoning & N/A & Ortega et al. (1978) [89] \\
\hline
\end{tabular}

*N/A: Not Applicable

Other evidences demonstrated the in vitro antimicrobial and antioxidant activity of methanol and water extracts of sweet and bitter apricot kernels (Prunus Armeniaca L.) (Table 2). The antioxidant properties of apricot kernels extract were evaluated by determining radical scavenging power; lipid peroxidation inhibition activity and total phenol content measured with a DPPH (2,2-diphenyl-1picrylhydrazyl, via electron paramagnetic resonance (EPR) signals, the thiocyanate method and the Folin method. $[45,46,47,48]$ On contrary, the extracts of the bitter 
kernels, both the water and methanol extracts of sweet kernels have been proved to be associated with antioxidant efficacy. [45,46,47,48] The maximum percent inhibition of lipid peroxidation (69\%) and the total phenolic content were detected in the methanol extract and in the water extract of the same cultivar of sweet kernels (Hasanbey). [45,46,47,48] Antimicrobial activities against human pathogenic microorganisms were also tested using the above extracts by a disc-diffusion method.

The effect of Amygdalin in colorectal cancer has also been studied. [49] Microarray studies indicated that Amygdalin down regulated genes belonging to cell cycle category: exonuclease 1 (EXO1), ATP-binding cassette, sub-family F, member 2 (ABCF2), MRE11 meiotic recombination 11 homolog A (MRE11A), topoisomerase (DNA) 1 (TOP1), and FK506 binding protein 12rapamycin-associated protein 1 (FRAP1). Reverse Transcription- Polymerase Chain Reaction (RT-PCR) analysis confirmed that mRNA levels of these genes were also decreased by Amygdalin treatment in SNU-C4 human colon cancer cells. [49] These findings indicated that Amygdalin could be associated with anticancer effect via down regulation of cell cycle-related genes in SNU-C4 human colon cancer cells. These findings strongly indicate that Amygdalin could be used as a therapeutic anticancer drug [49].

\section{Triptolide and Amydgalin as Toxic Agents}

\section{Triptolide}

Trypterygium has also been reported as a toxic herb possibly causing liver injury, genetic damage, and birth defects. [50,51,52,53,54] However, it is not proven that isolated extracts of Trypterygium could be safe. Thus, Tao $\mathrm{X}$ et al (2000) suggested that all forms of herbs extracts have to be avoided by pregnant women, young children, kidney and liver disease patients [54].

A study aimed to evaluate the effect of Triptolide in Rheumatoid Arthritis revealed antifertility effect in men participated in the trial. Mean sperm density and motility were lower in the treatment arm versus the control, while follicle-stimulating hormone was higher in the treatment group. [55,56,57,58,59] However, testosterone levels and libido had been shown without any effect. Similar observations have been reported for related animal studies. $[55,56,57,58,59]$ Furthermore these compounds had direct effect on sperm development as well as testosterone levels, with sperm returning to normal after 6 weeks. However, high quality clinical trials are lacking to confirm efficacy and safety (Table 1) [55,56,57,58,59].

Even though clinical studies demonstrated positive effects of extracts in renal-associated conditions, such as renal transplant and idiopathic refractory nephrotic syndrome, the effects were suggested to be due to immune-modulation rather than direct activity on the kidney (Table 1). [60,61] One out of several clinical trials examined the effect of Triptolide in renal transplant recipients over five years. However, this was not a clinical study. [60] In a separate study, from the same group that lasted more than a year, the effect on sirolimus-induced proteinuria in similar patients was evaluated. [61] Several previous clinical trials, included in a meta-analysis on idiopathic refractory nephrotic syndrome, indicated beneficial effects on laboratory indices such as hypoalbuminemia, proteinuria, edema, and hypercholesterolemia. [62] Further animal and human studies, as well as in vitro models, indicated that "Thunder God Vine" extracts exert effects in autoimmune diseases. Interference in transcription of cytokines, prostaglandin secretion, response of mononuclear cells, generation of cytotoxic Tcells, IL-2 production, and inhibition of T-cell and B-cell proliferation were among the suggested mechanisms. $[63,64,65,67]$ The major immunosuppressive activity was suggested to be due to the effect of diterpenoids, triptolide and tripdiolide, while other chemical compounds such as dihydroagarofurans, alkaloids, tripchlorolides, and triterpenes could also be involved [68,69,70].

Only a very small number of clinical trials have been conducted under appropriate methodological protocols and under specific guidelines.

However, in those few trials that do meet quality protocol criteria, Triptolide was reported with beneficial effects on RA symptoms but was associated with clinically important side effects (Table 1). [71,72] Moreover Tao XL et al $(1989,2002)$ demonstrated improvement in patient and physician rated tenderness, swelling, and morning stiffness following treatment with Triptolide. Laboratory tests including erythrocyte sedimentation rate, immunoglobulin $\mathrm{G}$, immunoglobulin $\mathrm{M}$, immunoglobulin $\mathrm{A}$, and C-reactive protein were evaluated and showed improvement. [73,74] A clinical trial was performed by in Coldbach et al (2009) and they found a greater effect of the Triptolide extract in treating RA patients over 24 weeks than the sulfasalazine, with similar adverse side effects [75].

\section{Amygdalin}

Amygdalin is a cyanogenic glycoside mostly found in apricot kernels, bitter almonds and other seeds. [76] It is commonly known as Laetrile (the synthesized form of Amygdalin) or as vitamin B17; a drug that has been advocated variously as a cure for several types of cancer. $[76,77]$ However none of these claims have been substantiated. The question of whether Laetrile has a positive cancer treatment efficacy is still unclear. [78] Numerous animal studies have been reported showing that Amygdalin has a lack of efficacy (Table 2). No clinical study was able to show Amygdalin to have clear therapeutic effects. [79] On the other hand; Amygdalin has been associated with toxic and lethal side effects in animal and human studies [80-88].

In an earlier study, Amygdalin fed to dogs produced cyanide toxicity when the compound was consumed together with sweet almonds a food containing glucosidase, the enzyme known to hydrolyze Amygdalin to release cyanide. In addition, an observed sign of respiratory, cardiac and neurological impairment was resulted infertility due to cyanide-poisoning. [86,87,88,89] These earlier studies had focused on the acute toxicity of Amygdalin and addressed the potential for chronic cyanide toxicity associated with Amygdalin $[86,87,88,89]$.

\section{Our point of view}

Overall, this review shows that a controversy exist with the use of the natural aforementioned extracts and further studies are therefore necessary to determine the true properties of those agents on the treatment of cancer. Moreover, to date those natural compounds were tested in 
vitro, in vivo, and ex vivo in both animal and human cancer cell lines. Even though several reports demonstrated positive actions of both Triptolide and Amydgalin that could pave the way for further clinical trials on patients with lethal and terminal malignancies. However, high dosages of these agents may promote side effects and so further studies are required to confirm and determine these effects.

In Conclusion the present review demonstrate the advantages and disadvantages of the use of Triptolide and Amygdalin for the treatment of cancers. Existing therapies on cancer are known to be highly toxic with severe side effects that reduce the quality of life of the patients with no more than 6 months life expectancy. It is more that consoling to proceed with further studies on these bioactive natural molecules. Finally, further experimental tests as well as properly designed randomized, double blind trials have to be performed, in order to conclusively report any possible anticancer efficacy of Triptolide as well as Amygdalin natural agents.

\section{Disclosure}

All authors declare no any conflict of interest.

\section{References}

[1] Corson, T.W.; Crews, C.M. Molecular understanding and modern application of traditional medicines: Triumphs and trials. Cell 2007, 130, 769-774.

[2] Zhou, G.B.; Chen, S.J.; Wang, Z.Y.; Chen, Z. Back to the future of oridonin: again, compound from medicinal herb shows potent antileukemia efficacies in vitro and in vivo. Cell Res. 2007, 17,274-276.

[3] Helmstädter, A. Tripterygium wilfordii Hook. f. - how a traditional Taiwanese medicinal plant found its way to the West. Die Pharmazie - Die Pharmazie - An International Journal of Pharmaceutical Sciences. 2013, 68, 7, 643-646(4).

[4] Goldbach-Mansky, R.; Wilson, M.; Fleischmann, R.; Olsen, N.; Silverfield, J.; Kempf, P.; Kivitz, A.; Sherrer, Y.; Pucino, F.; Csako, G.; et al. Comparison of Tripterygium wilfordii Hook F Versus Sulfasalazine in the Treatment of Rheumatoid Arthritis A Randomized Trial. Ann. Intern. Med. 2009, 151, 229-251.

[5] Tao, X.L.; Lipsky, P.E. The Chinese anti-inflammatory and immunosuppressive herbal remedy Tripterygium wilfordii Hook F. Rheum. Dis. Clin. N. Amer. 2000, 26, 2950.

[6] Ren, J.; Tao, Q.S.; Wang, X.B.; Wang, Z.M.; Li, J.S. Efficacy of T2 in active Crohn's disease: A prospective study report. Dig. Dis. Sci. 2007, 52, 1790-1797.

[7] Ji, S.M.; Wang, Q.W.; Chen, J.S.; Sha, G.Z.; Liu, Z.H.; Li, L.S. Clinical trial of Tripterygium wilfordii Hook F. in human kidney transplantation in China. Transplant. Proc. 2006, 38, 1274-1279.

[8] Chan, E.W.C.; Cheng, S.C.S.; Sin, F.W.Y.; Xie, Y. Triptolide induced cytotoxic effects on human promyelocytic leukemia, $\mathrm{T}$ cell lymphoma and human hepatocellular carcinoma cell lines. Toxicol. Lett. 2001, 122, 81-87.

[9] Carter, B.Z.; Mak, D.H.; Schober, W.D.; Dietrich, M.F.; Pinilla, C.; Vassilev, L.T.; Reed, J.C.; Andreeff, M. Triptolide sensitizes AML cells to TRAIL-induced apoptosis via decrease of XIAP and p53-mediated increase of DR5. Blood 2008, 111, 3742-3750.

[10] Zhou, G.S.; Hu, Z.; Fang, H.T.; Zhang, F.X.; Pan, X.F.; Chen, X.Q.; Hu, A.M.; Xu, L.; Zhou, G.B. Biologic activity of triptolide in $\mathrm{t}(8 ; 21)$ acute myeloid leukemia cells. Leuk. Res. 2011, 35, 214218.

[11] Jiang, X.H.; Wong, B.C.Y.; Lin, M.C.M.; Zhu, G.H.; Kung, H.F.; Jiang, S.H.; Yang, D.; Lam, S.K. Functional p53 is required for triptolide-induced apoptosis and AP-1 and nuclear factor-kappa B activation in gastric cancer cells. Oncogene 2001, 20, 8009-8018.
[12] Chen, Y.W.; Lin, G.J.; Chia, W.T.; Lin, C.K.; Chuang, Y.P.; Sytwu, H.K. Triptolide exerts anti-tumor effect on oral cancer and KB cells in vitro and in vivo. Oral Oncol. 2009, 45, 562-568.

[13] Wang, Z.P.; Jin, H.F.; Xu, R.D.; Mei, Q.B.; Fan, D.M. Triptolide downregulates Rac1 and the JAK/STAT3 pathway and inhibits colitis-related colon cancer progression. Exp. Mol. Med. 2009, 41, 717-727.

[14] Liu, Y.A.; Zeng, L.L.; Chen, Y.; Zhao, F.; Li, R.; Zhang, C.; Wen, L. Triptolide inhibits cell growth and induces G0-G1 arrest by regulating P21wap1/cip1 and P27 kip1 in human multiple myeloma RPMI-8226 cells. Chin. J. Cancer Res. 2010, 22, 141147.

[15] Kim, M.J.; Lee, T.H.; Kim, S.H.; Choi, Y.J.; Heo, J.; Kim, Y.H. Triptolide inactivates Akt and induces caspase-dependent death in cervical cancer cells via the mitochondrial pathway. Int. J. Oncol. 2010, 37, 1177-1185.

[16] Tengchaisri, T.; Chawengkirttikul, R.; Rachaphaew, N.; Reutrakul, V.; Sangsuwan, R.; Sirisinha, S. Antitumor activity of triptolide against cholangiocarcinoma growth in vitro and in hamsters. Cancer Lett. 1998, 133, 169-175.

[17] Mujumdar, N.; Mackenzie, T.N.; Dudeja, V.; Chugh, R.; Antonoff, M.B.; Borja-Cacho, D.; Sangwan, V.; Dawra, R.; Vickers, S.M.; Saluja, A.K. Triptolide Induces Cell Death in Pancreatic Cancer Cells by Apoptotic and Autophagic Pathways. Gastroenterology 2010, 139, 598-608.

[18] Antonoff, M.B.; Chugh, R.; Skube, S.J.; Dudeja, V.; Borja-Cacho, D.; Clawson, K.A.; Vickers, S.M.; Saluja, A.K. Role of Hsp-70 in triptolide-mediated cell death of neuroblastoma. J. Surg. Res. 2010, 163, 72-78.

[19] Yang, S.M.; Chen, J.G.; Guo, Z.; Xu, X.M.; Wang, L.P.; Pei, X.F.; Yang, J.; Underhill, C.B.; Zhang, L.R. Triptolide inhibits the growth and metastasis of solid tumors. Mol. Cancer Ther. 2003, 2, 65-72. Molecules 2011, 165293.

[20] Phillips, P.A.; Dudeja, V.; McCarroll, J.A.; Borja-Cacho, D.; Dawra, R.K.; Grizzle, W.E.; Vickers, S.M.; Saluja, A.K. Triptolide induces pancreatic cancer cell death via inhibition of heat shock protein 70. Cancer Res. 2007, 67, 9407-9416.

[21] Antonoff, M.B.; Chugh, R.; Borja-Cacho, D.; Dudeja, V.; Clawson, K.A.; Skube, S.J.; Sorenson, B.S.; Saltzman, D.A.; Vickers, S.M.; Saluja, A.K. Triptolide therapy for neuroblastoma decreases cell viability in vitro and inhibits tumor growth in vivo. Surgery 2009, 146, 282-290.

[22] Shamon, L. A., Pezzuto, J. M., Graves, J. M., Mehta, R. R., Wangcharoentrakul, S., Sangsuwan, R., Chaichana, S., Tuchinda, P., Cleason, P., and Reutrakul, V. Evaluation of the mutagenic, cytotoxic, and antitumor potential of triptolide, a highly oxygenated diterpene isolated from Tripterygium wilfordii. Cancer Lett., 1997, 112: 113-117.

[23] Wei, Y. S., and Adachi, I. Inhibitory effect of triptolide on colony formation of breast and stomach cancer cell lines. Zhongguo Yaoli Xuebao, 1991, 12: 406-410.

[24] Graziose, R.; Lila, M.A.; Raskin, I. Merging traditional Chinese medicine with modern drug discovery technologies to find novel drugs and functional foods. Curr. Drug Discov. Technol. 2010, 7, $2-12$.

[25] Lipsky, P.E.; Tao, X.L. A potential new treatment for rheumatoid arthritis: Thunder god vine. Semin. Arthritis Rheum. 1997, 26, 713-723.

[26] Ma, J.; Dey, M.; Yang, H.; Poulev, A.; Pouleva, R.; Dorn, R.; Lipsky, P.E.; Kennelly, E.J.; Raskin, I. Anti-inflammatory and immuno suppressive compounds from Tripterygium wilfordii. Phytochemistry 2007, 68, 1172-1178.

[27] Qian, S.Z. Tripterygium wilfordii, a Chinese herb effective in male fertility regulation. Contraception 1987, 36, 335-345.

[28] Matlin, S.A.; Belenguer, A.; Stacey, V.E.; Qian, S.Z.; Xu, Y.; Zhang, J.W.; Sanders, J.K.; Amor, S.R.; Pearce, C.M. Male antifertility compounds from Tripterygium wilfordii Hook f. Contraception 1993, 47, 387-400.

[29] Chang H. K., Yang H. Y., Lee T. H., Shin M. C., Lee M. H., Shin M. S., Kim C. J., Kim O. J., Hong S. P., Cho S., Armeniacae semen extract suppresses lipopolysaccharide-induced expressions of cyclooxygenase [correction of cycloosygenase]-2 and inducible nitric oxide synthase in mouse BV2 microglial cells. Biol. Pharm. Bull., 2005, 28, 449-454.

[30] Hwang DR, Kang YS, Kim SS, Kim DH, Shin MK, Song HJ. Studies on the Allergic asthma effect of Semen Armeniaceae Amarum. Kor j herbol. 2003; 18:201-208. 
[31] Pak JU, Moon SJ, Moon K, Won JH. Effects of Seman Armenicae and Radix Trichosanthis on the iNOS expression and superoxide formation in the RAW264.7 cells. J Kor Orient Oncol. 1999; 5:137-150.

[32] Ellison NM, Byar DP, Newell GR. Special report on Laetrile: the NCI Laetrile Review. Results of the National Cancer Institute's retrospective Laetrile analysis. $N$ Engl J Med. 1978; 299:549-552.

[33] Fukuda T, Ito H, Mukainaka T, Tokuda H, Nishino H, Yoshida T. Anti-tumor promoting effect of glycosides from Prunus persica seeds. Biol Pharm Bull. 2003; 26:271-273.

[34] Shim B. S., Park J. K., Choi S. H., J. Kor. Orient. Oncol., 6, 2000, 19-28.

[35] Koo J. Y., Hwang E. Y., Cho S., Lee J. H., Lee Y. M., Hong S. P., Quantitative determination of amygdalin epimers from armeniacae semen by liquid chromatography J. Chromatogr. B Analyt. Technol. Biomed. Life Sci., 2005, 814, 69-73.

[36] Flora KP, Cradock JC, Ames MM. A simple method for the estimation of amygdalin in the urine. Res Commun Chem Pathol Pharmacol 1978; 20: 367-378.

[37] Khandekar JD, Edelman H. Studies of amygdalin (laetrile) toxicity in rodents. JAMA 1979; 242: 169-171.

[38] Moertel CG, Ames MM, Kovach JS, Moyer TP, Rubin JR, Tinker $\mathrm{JH}$. A pharmacologic and toxicological study of amygdalin. JAMA 1981; 245: 591-594.

[39] Fukuda T, Ito H, Mukainaka T, Tokuda H, Nishino H, Yoshida T. Anti-tumor promoting effect of glycosides from Prunus persica seeds. Biol Pharm Bull 2003; 26: 271-273.

[40] Kwon HY, Hong SP, Hahn DH, Kim JH. Apoptosis induction of Persicae Semen extract in human promyelocytic leukemia (HL-60) cells. Arch Pharm Res. 2003; 26: 157-161.

[41] Taija MK, Philip SL, Robert GS, et al. Antiproliferative and Proapoptotic Activities of Triptolide (PG490), a Natural Product Entering Clinical Trials, on Primary Cultures of Human Prostatic Epithelial Cells. Clin Cancer Reserch 2002:8:2666-2674.

[42] Fei Z, Weiwei H, Tamgue O, Bin Z, Yangyang H, Daguia Z, John C, Chen W, Huanhuan C, Huanan L, Xiaoyong R, Ming Lei. Triptolide Induces Growth Inhibition and Apoptosis of Human Laryngocarcinoma Cells by Enhancing p53 Activities and Suppressing E6-Mediated p53 Degradation. Molecules 2013: V:8 Issue 11 e80784.

[43] Zhipeng W, Haifeng J, Ruodan X, Qibing M, and Daiming F. Triptolide downregulates Rac1 and the JAK/STAT3 pathway and inhibits colitis-related colon cancer progression EXPERIMENTAL and MOLECULAR MEDICINE, 2009. Vol. 41, No. 10, 717-727.

[44] Hyun-Kyung C, Mal-Soon S, Hye-Young Y, Jin-Woo L, YoungSick K, Myoung-Hwa L, Jullia K, Khae-Hawn K, and Chang-Ju K. Amygdalin Induces Apoptosis through Regulation of Bax and Bcl2 Expressions in Human DU145 and LNCaP Prostate Cancer Cells. Biol. Pharm. Bull. 2006. 29 (8) 1597.

[45] Milazzo, S., Lejeune, S. \& Ernst, E. Laetrile for cancer: a systematic review of the clinical evidence. Support. Care Cancer 15, 583-595 (2007).

[46] Moertel CG, Fleming TR, Rubin J, Kvols LK, Sarna G, et al. A clinical trial of amygdalin (Laetrile) in the treatment of human cancer N Engl J Med 1982. 306: 201-206.

[47] Newell GR, Ellison NM Ethics and designs: laetrile trials as an example. Cancer Treat 1980. Rep 64: 363-365.

[48] Yi D, Yi N. and Mavi A. Antioxidant and antimicrobial activities of bitter and sweet apricot (Prunus armeniaca L) kernels. Brazilian Journal of Medical and Biological Research 2009 42: 346352 SSN 0100-879X.

[49] Hae-Jeong P, Seo-Hyun Y, Long-Shan H, Long-Tai Z, KyungHee J, Yoon-Kyung U, Je-Hyun L, Ji-Seon J, Woo-Sang J, SungVin Y, Joo-Ho C, Seon-Pyo H. Amygdalin inhibits genes related to cell cycle in SNU C4 human colon cancer cells. World Journal of Gastroenterology 2005 ISSN 1007-9327.

[50] Peng B, Miao MS, Wang YL, et al. Initial discussion of mice acute hepatic injury caused by tripterygium glycosides [in Chinese]. Zhongguo Zhong Yao Za Zhi. 2004;28:1067-70.

[51] Takei A, Nagashima G, Suzuki R, et al. Meningoencephalocele associated with Tripterygium wilfordii treatment. Pediatr Neurosurg. 1997; 27:45-48.

[52] Chan WY, Ng TB. Adverse effect of Tripterygium wilfordii extract on mouse embryonic development. Contraception. 1995;51:65-71.

[53] Xu W, Ziqing L, Yinrun D, et al. Tripterygium hypoglaucum (level) Hutch induces aneuploidy of chromosome 8 in mouse bone marrow cells and sperm. Mutagenesis. 2004; 19:379-82.
[54] Tao X, Lipsky PE. The Chinese anti-inflammatory and immunosuppressive herbal remedy Tripterygium wilfordii Hook $F$. Rheum Dis Clin North Am. 2000; 26:29-50, viii.

[55] Lopez LM, Grimes DA, Schulz KF. Nonhormonal drugs for contraception in men: a systematic review. Obstet Gynecol Surv. 2005; 60(11):746-752.

[56] Lue Y, Sinha Hikim AP, Wang C, et al. Triptolide: a potential male contraceptive. J Androl. 1998; 19(4):479-486.

[57] Zhen Q, Ye X, Wei ZJ. Recent progress in research on Tripterygium: a male antifertility plant. Contraception. 1995; 51(2): 121-129.

[58] Matlin SA, Belenguer A, Stacey VE, et al. Male antifertility compounds from Tripterygium wilfordii Hook $\mathrm{f}$ Contraception.1993; 47(4):387-400.

[59] Qian SZ. Tripterygium wilfordii, a Chinese herb effective in male fertility regulation. Contraception. 1987; 36(3):335-345.

[60] Ji SM, Wang QW, Chen JS, Sha GZ, Liu ZH, Li LS. Clinical trial of Tripterygium wilfordii Hook F. in human kidney transplantation in China. Transplant Proc. 2006; 38(5):1274-1279.

[61] Ji SM, Li LS, Wen JQ, et al. Therapeutic effect of Tripterygium wilfordii on proteinuria associated with sirolimus in renal transplant recipients. Transplant Proc. 2008; 40(10):3474-3478.

[62] Xu G, Tu W, Jiang D, Xu C. Tripterygium wilfordii Hook F treatment for idiopathic refractory nephrotic syndrome in adults: a meta-analysis. Nephron Clin Pract. 2009;111(4):c223-c228.

[63] Li XW, Weir MR. Radix Tripterygium wilfordii a Chinese herbal medicine with potent immunosuppressive properties. Transplantation. 1990;50(1):82-86.

[64] Chang DM, Chang WY, Kuo SY, Chang ML. The effects of traditional antirheumatic herbal medicines on immune response cells. J Rheumatol. 1997;24(3):436-441.

[65] Tao X, Davis LS, Lipsky PE. Effect of an extract of the Chinese herbal remedy Tripterygium wilfordii Hook F on human immune responsiveness. Arthritis Rheum. 1991;34(10):1274-1281.

[66] Ye WH. Mechanism of treating rheumatoid arthritis with polyglycosides of Tripterygium wilfordii Hook (T II). III. Study on inhibitory effect of T II on in vitro Ig secreted by peripheral blood mononuclear cells from normal controls and RA patients [in Chinese]. Zhongguo Yi Хие Ке Хие Yuan Хие Bao. 1990; 12(3): 217-222.

[67] Sylvester J, Liacini A, Li WQ, Dehnade F, Zafarullah M. Tripterygium wilfordii Hook $\mathrm{F}$ extract suppresses proinflammatory cytokine-induced expression of matrix metalloproteinase genes in articular chondrocytes by inhibiting activating protein-1 and nuclear factor-kappaB activities. Mol Pharmacol. 2001;59(5):1196-1205.

[68] Tao X, Cai JJ, Lipsky PE. The identity of immunosuppressive components of the ethyl acetate extract and chloroform methanol extract (T2) of Tripterygium wilfordii Hook. F. J Pharmacol Exp Ther. 1995;272(3):1305-1312.

[69] Tamaki T, Kawamura A, Komatsu Y, Kawamura H, Maruyama H, Morota T. Phenolic nortriterpene demethylzeylasteral: a new immunosuppressive component of Tripterygium wilfordii Hook f. Transplant Proc. 1996;28(3):1379-1380.

[70] Yu DQ, Zhang DM, Wang HB, Liang XT. Structure modification of triptolide, a diterpenoid from Tripterygium wilfordii [in Chinese]. Yaо Хие Хие Вао. 1992;27(11):830-836.

[71] Little CV, Parsons T. Herbal therapy for treating osteoarthritis. Cochrane Database Syst Rev. 2001;(1):CD002947.

[72] Cameron M, Gagnier JJ, Little CV, Parsons TJ, Blümle A, Chrubasik S. Evidence of effectiveness of herbal medicinal products in the treatment of arthritis. Part 2: rheumatoid arthritis. Phytother Res. 2009;23(12):1647-1662.

[73] Tao XL, Sun Y, Dong Y, et al. A prospective, controlled, doubleblind, cross-over study of Tripterygium wilfordii hook $\mathrm{F}$ in treatment of rheumatoid arthritis. Chin Med J (Engl). 1989; 102(5): 327-332.

[74] Tao X, Younger J, Fan FZ, Wang B, Lipsky PE. Benefit of an extract of Tripterygium wilfordii Hook $F$ in patients with rheumatoid arthritis: a double-blind, placebo-controlled study. Arthritis Rheum. 2002;46(7):1735-1743.

[75] Goldbach-Mansky R, Wilson M, Fleischmann R, et al. Comparison of Tripterygium wilfordii Hook F versus sulfasalazine in the treatment of rheumatoid arthritis: a randomized trial. Ann Intern Med. 2009;151(4):229-240, W49-W51.

[76] Conn EE: Cyanogenic glycosides, In Neuberger A, Jukes TH (Eds): International Review of Biochemistry, Biochemistry of Nutrition. Baltimore, Universty Park Press, 1979, pp 21-43. 
[77] Herbert V: Laetrile: The cult of cyanide-Promoting poison for profit. Am J Clin. Nutr. 1979. 32:1121-1158.

[78] Griffin GE: World Without Cancer-The Story of Vitamin B1,7. Thousand Oaks, CA, American Media, 1974.

[79] Lewis JP: Laetrile (Informed Opinion). West J Med. 1977. 127: 55-62,

[80] Schmidt ES, Newton GW, Saunders SM, et al: Laetrile toxicity studies in dogs. JAMA 1978. 239:943-947.

[81] Khandekar JD, Edelman H: Studies of amygdalin (laetrile) toxicity in rodents. JAMA 1979. 242:169-171.

[82] Smith FP, Butler TP, Cohan S, et al: Laetrile toxicity: A report of two cases. Chem Treat Rep 1978. 62:169-171.

[83] Humbert JR, Tress JH, Braico KT: Fatal cyanide poisoning: Accidental ingestion of amygdalin. JAMA 1977. 238:482.
[84] Sadoff L, Fuchs K, Hollander J: Rapid deaths associated with laetrile ingestion. JAMA 1978. 239:1532.

[85] Verdict of the coroner in the matter of the death of Jo Anne Etta Pye, February 1, 1979. Pathologist's Report Jan 26.

[86] Investigator's Report December 3, 1978. Alameda County Coroner's Department, County of Alameda, Oakland, CA.

[87] Anonymotus. Death blamed on cyanide-laetrile link. San Francisco Chronicle February 6, 1979.

[88] Anonymous. Laetrile poisoning takes third life, threatens fourth. Med. World News 20: 32, 1979.

[89] Ortega JA, Creek JE. Acute cyanide poisoning following administration of Laetrile J. Pediatr. 1978; 93: 1059. 